\title{
A. Nagy, Miskolc, Hungary \\ INVESTIGATION OF THE EFFECT OF AREAL ROUGHNESS MEASUREMENT LENGTH ON FACE MILLED SURFACE TOPOGRAPHIES
}

\begin{abstract}
Surface roughness is of great importance in the manufacturing industry, as it affects surfaces' tribological properties (wear, friction, lubrication, etc.), corrosion resistance, fatigue strength and appearance. Areal roughness measurement, which provides a more comprehensive characterization of surfaces, is becoming increasingly popular, but systematic studies are still lacking, so measurements are often analyzed differently. In this paper, the effect of the measurement length is analyzed in the main measurement direction on areal roughness of face milled surface topographies, which were measured with a confocal chromatic sensor.
\end{abstract}

Keywords: surface roughness; areal roughness; measurement length.

\section{INTRODUCTION}

One of the main quality factors of the machined surfaces of the parts is the surface roughness, as it influences their tribological properties (wear, friction, lubrication, etc.), their corrosion resistance, fatigue strength and their appearance. Two methods have been developed to investigate this, profile analysis and areal roughness analysis. The latter, which was later developed, is becoming more widespread in the scientific community as well as in industry, as 3D surfaces in terms of shape or functionality contain much more data thanks to the main and lateral directional measurement, and the surfaces cannot be characterized as distinctly by traditional 2D profile roughness parameters [1]. This is used for a wide variety of machining methods, some of which are briefly described, focusing on the method of measurement.

Roughness tests are often performed on experimentally machined surfaces worldwide. Eifler et al. [2] studied the roughness of micro-milled surfaces. The surfaces were compared in the measured areas with a F-operator to separate the shape and with an L-filter to filter out the waviness, and the resulting $600 \times 600 \mu \mathrm{m}^{2}$ roughness topographies were analyzed with the $S_{a}$ and $S_{q}$ parameter values. They found that the distance of the milling marks and the tilt angle of the milled surface had a significant effect on the roughness. During ultraprecision turning, Karpat [3] analyzed side surfaces created with a diamond tool. The outliers of the measurement results were filtered out and the topographies were leveled. The roughness was then separated from the waviness with the $8 \mu \mathrm{m}$ cut-off length of a Gaussian filter to obtain $144 \times 108 \mu \mathrm{m}^{2}$ areas for analysis. The effects of cutting edge angles, feed rate, and depth of cut were compared on roughness with parameters $S_{a}, S_{q}$, and $S_{z}$. It was found that the tool with the $30^{\circ}$ chamfer formed 
(C) A. Nagy, 2021

the surface with the lowest average roughness of $1 \mathrm{~nm}$ with a small depth of cut and feed. Zak [4] compared the textures of surfaces machined to nearly the same average roughness by several methods (hard turning, grinding, burnishing), developing a new approach to characterize surface topographies by area-scale fractal analysis. An area of $2.4 \times 2.4 \mathrm{~mm}^{2}$ was measured on each surface and the method of filtration was not mentioned. The surfaces and the effects of machining methods were characterized with the help of several roughness parameters: $S_{a}, S_{z}$, $\mathrm{S}_{\mathrm{sk}}, \mathrm{S}_{\mathrm{ku}}$, as well as $\mathrm{S}_{\mathrm{mr}}, \mathrm{S}_{\mathrm{mc}}, \mathrm{S}_{\mathrm{xp}}$, and with functional volume indices $\left(\mathrm{V}_{\mathrm{mp}}, \mathrm{V}_{\mathrm{mc}}, \mathrm{V}_{\mathrm{vc}}\right.$, $\mathrm{V}_{\mathrm{vv}}$ ). He found that the surface made with combined machining (turning and grinding) is better than the hard-turned surface in a functional point of view (load bearing, force sealing), while the grinded surface has a better ability to preserve fluid.

Many researcher groups study the topography of formed surfaces in SLM metal additive manufacturing. In Wüst et al. [5] $1 \times 1 \mathrm{~mm}^{2}$ areas were measured and an Sfilter and an L-filter were used in the evaluation. The values of the obtained $\mathrm{S}_{\mathrm{a}}$ index were compared with the surfaces machined by the hybrid additive method, where the feed rate increased, the depth of cut decreased the roughness. In another article, Cabanettes et al. [6] compared different machining strategies, characterizing the topographies at several levels (shape, waviness, roughness). A measurement area of $3.22 \times 1.90 \mathrm{~mm}^{2}$ was examined on the machined surfaces, the shape error was eliminated with a polynomial filter of order 2 to evaluate the topographies, and no other filter was applied. The surfaces were characterized by the values of the roughness parameters $S_{\mathrm{a}}, S_{\mathrm{z}}, S_{\mathrm{al}}, S_{\mathrm{tr}}, S_{\mathrm{dq}}$ and $S_{\mathrm{dr}}$. Charles et al. [7] analyzed the effects of different machining parameters on roughness. For this, $4 \times 4 \mathrm{~mm}^{2}$ areas were measured, and no filtering was mentioned on the topographies during evaluation. Surfaces have frequently been characterized by the average roughness $S_{a}$, which is becoming increasingly popular (including in additive machining).

The brief literature review above shows that the investigations of the settings of roughness measurement (size of the measured area, the filtering of topographies) on surfaces machined by different methods are carried out in various ways, and information is obtained from different selections of roughness indices for characterization and comparison. Based on the reviewed literature, it means that there is no unified method of areal roughness measurement, and thus the surfaces produced in different ways cannot actually be compared.

This article is a continuation of a previous study [8] and its aim is to analyze the effects of roughness measurement settings on the values of areal roughness parameters in order to select unified measurement conditions for later studies. In this paper, I examine whether and to what extent the roughness values are affected by varying the measurement length as a function of the feed rate which creates the periodicity. This is due to the fact that few researchers have addressed this, despite 
the relatively large number of roughness analyses. In our research group, for example, previous investigations have been carried out on several features of face milled surfaces [9], analyzed changes in theoretical roughness [10], or the effect of the feed rate on roughness $[11,12]$.

\section{EXPERIMENTAL CONDITIONS}

The experiments were performed on a PerfectJet MCV-M8 vertical milling machine on two C45 grade workpieces on which $50 \mathrm{~mm}$ long flat surfaces were produced by symmetrical face milling under dry conditions. Specimens were machined with a single Sandvik R215.44-15T308M-WL (grade GC4030) coated carbide insert in a Sandvik R252.44-080027-15M milling head on the machine, with the following cutting data set: constant cutting speed ( $\mathrm{vc}=300 \mathrm{~m} / \mathrm{min})$ and depth of cut (ap=0.8 mm), variable feed rates $\left(\mathrm{f}_{\mathrm{z}}=0.1 / 0.3 \mathrm{~mm} / \mathrm{rev}\right.$.). Due to the perpendicular position of the tool axis and the machined surface, double milling marks formed on the surfaces.

It was previously found that among cutting data the feed rate has the greatest influence on roughness [11], which is why we examine the roughness for the measurement length at several feeds. The reason for choosing the above values is that ISO 4288:1998 specifies different measurement and cut-off lengths for these feed rate values for surfaces with a periodic profile. The values selected accordingly are also recommended in ISO 25178-3:2012. Thus, this investigation is performed on several workpieces representing different standard cut-off lengths.

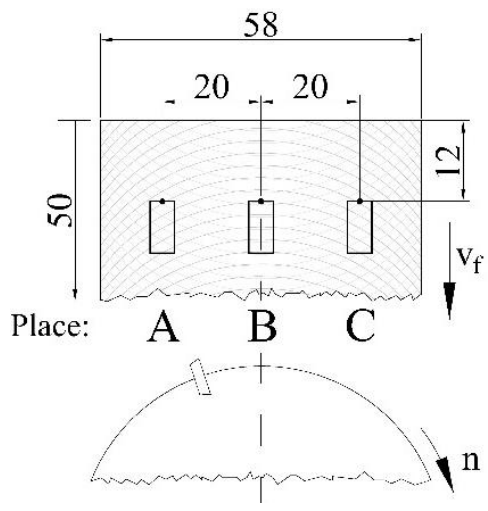

Figure 1 - Measuring places on the topographies

The instrument used for the measurement was an AltiSurf 520 type 3D surface roughness measuring device with a confocal chromatic sensor (CL2). Three measurement distances were recorded at the same distance, of which the middle area 
(B) was aligned to the milling symmetry plane (Fig. 1). It is necessary to examine several areas on the surfaces at the same time because all parts of functional surfaces are connected to their counterpart at once, where roughness plays an important role. In addition, due to kinematic conditions, face milling is characterized by a variety of roughness impressions, so that roughness differs on different parts of the surface [12]. The measured topographies were uniformly $4 \mathrm{~mm}$ wide (perpendicular to the feed direction), and the length was varied (in the feed direction) determined on basis of the feed. These are characterized by the value $p$, which shows the feed per tooth in the measurement length.

Table 1 - Roughness values measured on specimen of $\mathrm{f}_{\mathrm{z}}=0.1 \mathrm{~mm} / \mathrm{rev}$

\begin{tabular}{|c|l|l|l|l|l|l|l|l|l|l|l|}
\hline \multicolumn{2}{|c|}{$\mathbf{p}[-]$} & $\mathbf{3}$ & $\mathbf{4}$ & $\mathbf{5}$ & $\mathbf{7}$ & $\mathbf{9}$ & $\mathbf{1 0}$ & $\mathbf{1 5}$ & $\mathbf{2 0}$ & $\mathbf{2 5}$ & $\mathbf{3 0}$ \\
\hline \hline length $[\mathrm{mm}]$ & $\mathbf{0 . 3}$ & $\mathbf{0 . 4}$ & $\mathbf{0 . 5}$ & $\mathbf{0 . 7}$ & $\mathbf{0 . 9}$ & $\mathbf{1}$ & $\mathbf{1 . 5}$ & $\mathbf{2}$ & $\mathbf{2 . 5}$ & $\mathbf{3}$ \\
\hline & $\mathbf{A}$ & 0.436 & 0.438 & 0.440 & 0.443 & 0.442 & 0.445 & 0.445 & 0.445 & 0.448 & 0.448 \\
\hline $\mathbf{S}_{\mathbf{a}}[\mu \mathrm{m}]$ & $\mathbf{B}$ & 0.417 & 0.423 & 0.427 & 0.430 & 0.430 & 0.434 & 0.433 & 0.433 & 0.434 & 0.434 \\
\hline & $\mathbf{C}$ & 0.356 & 0.363 & 0.363 & 0.361 & 0.360 & 0.361 & 0.361 & 0.359 & 0.361 & 0.360 \\
\hline & $\mathbf{A}$ & 0.516 & 0.519 & 0.521 & 0.523 & 0.523 & 0.525 & 0.526 & 0.525 & 0.529 & 0.528 \\
\hline $\mathbf{S}_{\mathbf{q}}[\mu \mathrm{m}]$ & $\mathbf{B}$ & 0.483 & 0.491 & 0.496 & 0.497 & 0.497 & 0.501 & 0.500 & 0.500 & 0.502 & 0.502 \\
\hline & $\mathbf{C}$ & 0.432 & 0.441 & 0.440 & 0.438 & 0.437 & 0.439 & 0.439 & 0.437 & 0.439 & 0.438 \\
\hline & $\mathbf{A}$ & 2.886 & 2.916 & 3.000 & 2.995 & 2.984 & 3.087 & 3.198 & 3.259 & 3.294 & 3.272 \\
\hline $\mathbf{S}_{\mathbf{z}}[\mu \mathrm{m}]$ & $\mathbf{B}$ & 2.336 & 2.505 & 2.518 & 2.556 & 2.656 & 2.599 & 2.634 & 2.646 & 2.645 & 2.664 \\
\hline & $\mathbf{C}$ & 2.142 & 2.343 & 2.332 & 2.342 & 2.381 & 2.450 & 2.420 & 2.406 & 2.437 & 2.579 \\
\hline & $\mathbf{A}$ & 0.518 & 0.518 & 0.521 & 0.510 & 0.514 & 0.509 & 0.507 & 0.504 & 0.495 & 0.497 \\
\hline $\mathbf{S}_{\text {sk }[-]}$ & $\mathbf{B}$ & 0.440 & 0.456 & 0.481 & 0.462 & 0.452 & 0.450 & 0.455 & 0.453 & 0.457 & 0.457 \\
\hline & $\mathbf{C}$ & 0.583 & 0.584 & 0.582 & 0.583 & 0.587 & 0.584 & 0.586 & 0.585 & 0.585 & 0.585 \\
\hline & $\mathbf{A}$ & 2.194 & 2.202 & 2.204 & 2.181 & 2.186 & 2.188 & 2.185 & 2.172 & 2.167 & 2.170 \\
\hline $\mathbf{S}_{\mathbf{k u}}[-]$ & $\mathbf{B}$ & 1.991 & 2.021 & 2.027 & 2.005 & 1.983 & 1.980 & 1.985 & 1.968 & 1.991 & 1.986 \\
\hline & $\mathbf{C}$ & 2.211 & 2.243 & 2.241 & 2.235 & 2.236 & 2.233 & 2.231 & 2.226 & 2.234 & 2.233 \\
\hline
\end{tabular}

In ISO 4288:1998, for surfaces with a periodic profile, the measurement lengths were determined so that the profile contained 10-25 times the mean width of the profile elements $\left(R_{S m}\right)$ [13]. This range, if a long enough surface is available for the measurement, proves to be sufficient in most cases so that there is neither too little nor too many outliers (due to machining errors) relative to the total measurement length, which would skew the results. Based on this, I chose values which are multipiles of the feed; between $p=3-30$ for this study. 
The evaluation was carried out with AltiMap Premium software, where after leveling the topographies and eliminating the outliers, I set the cut-off lengths according to the above-mentioned standard (at 0.25 and $0.8 \mathrm{~mm}$, respectively).

\section{RESULTS AND DISCUSSION}

Tables 1 and 2 show the measurement results on the surfaces of the two specimens for the most commonly used 3D roughness parameters [14], arranged according to the three measurement places and the different measurement lengths. Each measurement was repeated three times, the reported values being the arithmetic means of the three results. The relative differences of the results by parameter and measurement location are shown in diagrams in Figure 2 for the two workpieces.

The diagrams show similar characteristics. The most important finding is that with the increase of the measurement length, the difference in the values is noticeable initially, after that the measured values show little deviation. This means that any value of $p$ can be set, as the measurement length hardly affects the measured values.

Table 2 - Roughness values measured on specimen of $\mathrm{f}_{\mathrm{z}}=0.3 \mathrm{~mm} / \mathrm{rev}$.

\begin{tabular}{|c|c|c|c|c|c|c|c|c|c|c|c|}
\hline & 3 & 4 & 5 & 7 & 9 & 10 & 15 & 20 & 25 & 30 \\
\hline \multicolumn{2}{|c|}{ length $[\mathrm{mm}]$} & 0.9 & 1.2 & 1.5 & 2.1 & 2.7 & 3 & 4.5 & 6 & 7.5 & 9 \\
\hline \multirow{3}{*}{$\mathbf{S}_{\mathbf{a}}[\mu \mathrm{m}]$} & A & 1.858 & 1.859 & 1.860 & 1.861 & 1.861 & 1.859 & 1.856 & 1.854 & \begin{tabular}{|l|l|}
1.854 \\
\end{tabular} & 1.854 \\
\hline & B & 2.238 & 2.244 & 2.245 & 2.244 & 2.249 & 2.241 & 2.248 & 2.249 & 2.250 & 2.251 \\
\hline & C & 1.059 & 1.060 & 1.060 & 1.064 & 1.064 & 1.064 & 1.066 & 1.068 & \begin{tabular}{|l|l|}
1.068 \\
\end{tabular} & 1.069 \\
\hline \multirow{3}{*}{$\mathbf{S}_{\mathbf{q}}[\mu \mathrm{m}]$} & A & 2.131 & 2.131 & 2.132 & 2.134 & 2.134 & 2.129 & 2.128 & 2.126 & 2.126 & 2.125 \\
\hline & B & 2.546 & 2.553 & 2.553 & 2.552 & 2.559 & 2.548 & 2.558 & 2.558 & 2.560 & 2.562 \\
\hline & C & 1.410 & 1.411 & 1.410 & 1.413 & 1.413 & 1.414 & 1.415 & 1.416 & 1.416 & 1.417 \\
\hline \multirow{3}{*}{$\mathbf{S}_{\mathbf{z}}[\mu \mathrm{m}]$} & A & 8.060 & 8.001 & 8.021 & 7.981 & 8.171 & 8.200 & 8.161 & 8.177 & 8.185 & 8.265 \\
\hline & B & 9.0 & 9.037 & 8.985 & 8.89 & 8.965 & 8.999 & .034 & 6 & 8.940 & \\
\hline & C & 1.3 & 38 & 7.379 & 7.514 & 7.64 & 7. & 7.612 & 42 & 7.633 & 7.689 \\
\hline \multirow{3}{*}{$\mathbf{S}_{\mathbf{s k}}[-]$} & $\mathbf{A}$ & 0.55 & 0.554 & 0.554 & 0.553 & 0.551 & 0.547 & 0.545 & 0.544 & \begin{tabular}{|l|l|}
0.544 \\
\end{tabular} & 0.545 \\
\hline & B & 0.458 & 0.452 & 0.446 & 0.440 & 0.438 & 0.421 & 0.436 & 0.436 & 0.437 & 0.440 \\
\hline & C & 1.3 & 1.308 & 1.308 & 1.298 & 1.298 & 1.295 & 1.289 & 1.280 & 1.277 & 1.279 \\
\hline \multirow{3}{*}{$\mathbf{S}_{\mathbf{k u}}[-]$} & A & 1.999 & 1.997 & 1.996 & 1.996 & 1.993 & 1.987 & 1.990 & 1.988 & \begin{tabular}{|l|l|}
1.988 \\
\end{tabular} & 1.989 \\
\hline & B & 1.866 & 1.861 & 1.855 & 1.852 & 1.849 & 1.834 & 1.847 & 1.844 & \begin{tabular}{|l|l|}
1.842 \\
\end{tabular} & 1.845 \\
\hline & C & 4.235 & 4.220 & 4.216 & 4.193 & 4.191 & 4.182 & 4.170 & 4.147 & \begin{tabular}{|l|}
4.140 \\
\end{tabular} & 4.141 \\
\hline
\end{tabular}

The values of the arithmetic mean roughness $S_{a}$ and the root-mean-square average roughness $S_{\mathrm{q}}$ show the same characteristic on a workpiece and at a measuring place. With increasing $p$, in most cases the values first increase $(p \leq 12.5)$ and then remain nearly the same. Although with a larger deviation, the same can be 
stated for the maximum height parameter $S_{\mathrm{z}}$. The values of the dimensionless skewness $S_{\mathrm{sk}}$ and kurtosis $S_{\mathrm{ku}}$ initially decrease, and then at $p \leq 15$ they are unaffected by the length.

In Tables 3 and 4, the deviations of the values are reported according to the indicated $p-p$ interval, the signed $\mathrm{S}_{\mathrm{i}}$ roughness parameter, and the shown measurement location, using the following difference (1) and percentage (2) formulas:

$$
\begin{aligned}
\text { Differences of values } & =\max \left(S_{i}\right)-\min \left(S_{i}\right) \\
\text { Percentage value differences } & =\frac{\max \left(S_{i}\right)-\min \left(S_{i}\right)}{\operatorname{average}\left(S_{i}\right)}[\%]
\end{aligned}
$$

Since the values stabilized in most cases with increasing $p$ in Figure 2, the ranges in the tables were aligned to the largest $30 \times$ length examined. This is because the longer the length, in theory the better the irregularities are distributed on the topographies, the values are more averaged, which is generally expected for the parameters $S_{\mathrm{a}}$ and $\mathrm{S}_{\mathrm{q}}$.

Tables 3 and 4 show decreasing values in each case (one parameter, one measurement place) together with the narrowing of the ranges. This makes it clear that the longer measurement length (in the examined range) results in a smaller deviation in value, i.e., the measurement results have lower error values in the narrower intervals.

\begin{tabular}{|c|c|c|c|c|c|c|c|c|c|c|c|}
\hline \multicolumn{2}{|c|}{$\begin{array}{c}\text { p-p } \\
\text { interval }\end{array}$} & \multicolumn{2}{|c|}{ 3-30 } & \multicolumn{2}{|c|}{$10-30$} & \multicolumn{2}{|c|}{$15-30$} & \multicolumn{2}{|c|}{$20-30$} & \multicolumn{2}{|c|}{$25-30$} \\
\hline \multirow{3}{*}{$\begin{array}{c}\mathbf{S}_{\mathbf{a}} \\
{[\mu \mathrm{m}]}\end{array}$} & $\mathbf{A}$ & 0.012 & $67 \%$ & 006 & $1.34 \%$ & 004 & $82 \%$ & 003 & $0.72 \%$ & .001 & $\overline{50}$ \\
\hline & B & 0.018 & $\%$ & 3 & 0.7 & & & & & & \\
\hline & C & 0.007 & $2.05 \%$ & 0 & 0.5 & .0 & & 0.0 & & $\overline{0 .}$ & \\
\hline \multirow{3}{*}{$\begin{array}{c}\mathbf{S}_{\mathbf{q}} \\
{[\mu \mathrm{m}]}\end{array}$} & $\mathbf{A}$ & 0.012 & $\%$ & 006 & $1.17 \%$ & 0.003 & $\%$ & 0.003 & & 01 & $\%$ \\
\hline & B & 0.020 & $92 \%$ & 0.003 & $0.67 \%$ & 3 & $4 \%$ & 0.003 & $0.54 \%$ & 0.001 & $13 \%$ \\
\hline & C & 0.009 & $2.08 \%$ & 2 & $0.51 \%$ & 2 & $\%$ & 0 & $0.51 \%$ & 01 & $1 \%$ \\
\hline \multirow{3}{*}{$\begin{array}{c}\mathbf{S}_{\mathbf{z}} \\
{[\mu \mathrm{m}]}\end{array}$} & A & 0.457 & $14.66 \%$ & 0.290 & $8.97 \%$ & 0.145 & $4.42 \%$ & 0.084 & $2.54 \%$ & 24 & $74 \%$ \\
\hline & B & 0.331 & $12.79^{\circ}$ & 0.070 & $2.67 \%$ & 3 & $1.26 \%$ & 0.023 & $0.85 \%$ & 0.023 & $85 \%$ \\
\hline & C & 0.43 & $.23 \%$ & 0.1 & $7.40 \%$ & 2 & $7.00 \%$ & 0. & $6.96 \%$ & 0. & $4 \%$ \\
\hline \multirow{3}{*}{$\mathbf{S}_{\mathbf{s k}}[-]$} & A & 0.026 & $5.07 \%$ & 0 & 3.4 & 2 & $2.39 \%$ & 0.009 & $1.71 \%$ & 0.002 & $41 \%$ \\
\hline & B & .04 & $96 \%$ & 0.011 & 2. & 8 & 1. & 0. & $3 \%$ & 3 & $8 \%$ \\
\hline & C & & & & & & & 1 & & 1 & $15 \%$ \\
\hline \multirow{3}{*}{$\mathbf{S}_{\mathbf{k u}}[-]$} & $\mathbf{A}$ & 0.043 & $8 \%$ & & $1.24 \%$ & .023 & $1.07 \%$ & 0. & $0.49 \%$ & 0. & $.14 \%$ \\
\hline & B & 0.064 & 5 & 028 & $1.43 \%$ & .0 & $1.43 \%$ & 0.0 & $1.43 \%$ & 0.008 & $0.43 \%$ \\
\hline & C & 0.032 & $1.45 \%$ & 0.012 & $0.52 \%$ & 0.012 & $0.52 \%$ & 0.012 & $0.52 \%$ & 0.001 & $0.05 \%$ \\
\hline
\end{tabular}

Table 3 - Differences in roughness values for $\mathrm{f}_{\mathrm{z}}=0.1 \mathrm{~mm} / \mathrm{rev}$ 
Table 4 - Differences in roughness values for $\mathrm{fz}=0.3 \mathrm{~mm} / \mathrm{rev}$

\begin{tabular}{|c|c|c|c|c|c|c|c|c|c|c|c|}
\hline \multicolumn{2}{|c|}{$\begin{array}{c}\text { p-p } \\
\text { interval }\end{array}$} & \multicolumn{2}{|c|}{ 3-30 } & \multicolumn{2}{|c|}{$10-30$} & \multicolumn{2}{|c|}{$15-30$} & \multicolumn{2}{|c|}{$20-30$} & \multicolumn{2}{|c|}{ 25-30 } \\
\hline \multirow{3}{*}{$\mathbf{S}_{\mathbf{a}}[\mu \mathrm{m}]$} & $\mathbf{A}$ & 008 & $45 \%$ & 007 & 37 & .002 & $0.11 \%$ & 0.001 & 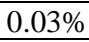 & 0.000 & $\%$ \\
\hline & B & .013 & & 010 & & 0.006 & & 04 & & & \\
\hline & $\mathrm{C}$ & .010 & & & & & $5 \%$ & & & & \\
\hline \multirow{3}{*}{$\mathbf{S}_{\mathbf{q}}[\mu \mathrm{m}]$} & $\mathbf{A}$ & .010 & $8 \%$ & .008 & $\%$ & 0.003 & $\%$ & 1 & & .000 & $2 \%$ \\
\hline & B & .016 & & 4 & & & & 0.006 & & 06 & \\
\hline & $\mathbf{C}$ & & & & & & & & & & \\
\hline \multirow{3}{*}{$\mathbf{S}_{\mathbf{z}}[\mu \mathrm{m}]$} & $\mathbf{A}$ & .284 & $3.49 \%$ & .130 & $1.59 \%$ & 04 & $1.26 \%$ & 88 & $7 \%$ & 0.085 & $3 \%$ \\
\hline & B & .297 & $3.30 \%$ & 247 & $2.75 \%$ & 0.231 & $2.56 \%$ & 0.231 & $6 \%$ & .231 & $6 \%$ \\
\hline & C & & & & & & & & & & \\
\hline \multirow{3}{*}{$\mathbf{S}_{\mathbf{s k}}[-]$} & A & 0.014 & $2.46 \%$ & 0.007 & $1.31 \%$ & 0.002 & $\%$ & 0.001 & $5 \%$ & 0.000 & $8 \%$ \\
\hline & B & 0.037 & $8.42 \%$ & 0.019 & $4.44 \%$ & 0.015 & $3.39 \%$ & 0.012 & $9 \%$ & 0.008 & $91 \%$ \\
\hline & $\mathrm{C}$ & & & & & & & & & 0.002 & \\
\hline \multirow{3}{*}{$\mathbf{S}_{\mathbf{k u}}[-]$} & $\mathbf{A}$ & 0.012 & $0.61 \%$ & 0.005 & $0.26 \%$ & 0.003 & $0.16 \%$ & 0.002 & $0.08 \%$ & 0.000 & $0.03 \%$ \\
\hline & B & 0.032 & $1.71 \%$ & 0.014 & $7 \%$ & 0.010 & $0.52 \%$ & 0.007 & $0.40 \%$ & 0.007 & $0.37 \%$ \\
\hline & C & 0.095 & $2.28 \%$ & 0.045 & $1.09 \%$ & 0.031 & $0.75 \%$ & 0.008 & $0.19 \%$ & 0.002 & $0.05 \%$ \\
\hline
\end{tabular}

The increase of the feed rate globally does not affect the deviation values. However, the magnitudes of the percentage deviations are usually smaller, as can be expected from the basis of the larger roughness values $\left(S_{\mathrm{a}}, \mathrm{S}_{\mathrm{q}}, \mathrm{S}_{\mathrm{z}}\right)$. In the case of $\mathrm{S}_{\mathrm{sk}}$ and $\mathrm{S}_{\mathrm{ku}}$, they do not necessarily decrease.

As for the roughness values, the differences are the greatest for the $S_{z}$ index. These are quite large over the entire study range; $0.25-0.5 \mu \mathrm{m}$ and with it, even $19 \%$ is possible, but by increasing the length, even in the case of $p \geq 10 \mathrm{~S}_{\mathrm{z}}$ remains below $0.3 \mu \mathrm{m}$ and $9 \%$.

In terms of $\mathrm{S}_{\mathrm{a}}, \mathrm{S}_{\mathrm{q}}$ indices, deviations of less than $1 \%$ can already be achieved for $p \geq 15$. In the same way, they remain below $7 \%$ for $S_{z}, 3.5 \%$ for $S_{\text {sk }}$, and $1.5 \%$ for $S_{\mathrm{ku}}$. These magnitudes of the difference are small, and also, in the three intervals designated between $p=15-30$, the decrease of the values in the table analyzed by row is not significant. It can also be seen to what extent the change of the measurement length influences the values of the examined roughness parameters; these are in descending order: $S_{\mathrm{z}}, \mathrm{S}_{\mathrm{sk}}, \mathrm{S}_{\mathrm{ku}}, \mathrm{S}_{\mathrm{q}}, \mathrm{S}_{\mathrm{a}}$.

For the measurement locations, the following relations can be seen to each roughness index. For $S_{a}$, the deviation is maximal in place $\mathbf{B}$, and these values in the side places are smaller and are close to each other. In the case of the $\mathrm{S}_{\mathrm{q}}$ index, the differences are always minimal, at $0.2-2.1 \%$ at location $\mathbf{C}$, the deviations at $\mathbf{A}$ and $\mathbf{B}$ are very similar. For the $S_{\mathrm{sk}}$ and $S_{\mathrm{ku}}$ parameters, the smaller differences are found at the lateral measurement places, the maximal values for the kurtosis are in the middle place at the lower feed, and on the exit side at the higher feed rate. The 
ratio of the values of $S_{z}$ varies between measurement sites for the $p$ - $p$ ranges, here any regularity cannot be identified. Thus, if the five examined parameters are considered together, the relationship between the measurement locations varies regardless of the feed, so the deviation is not regular.

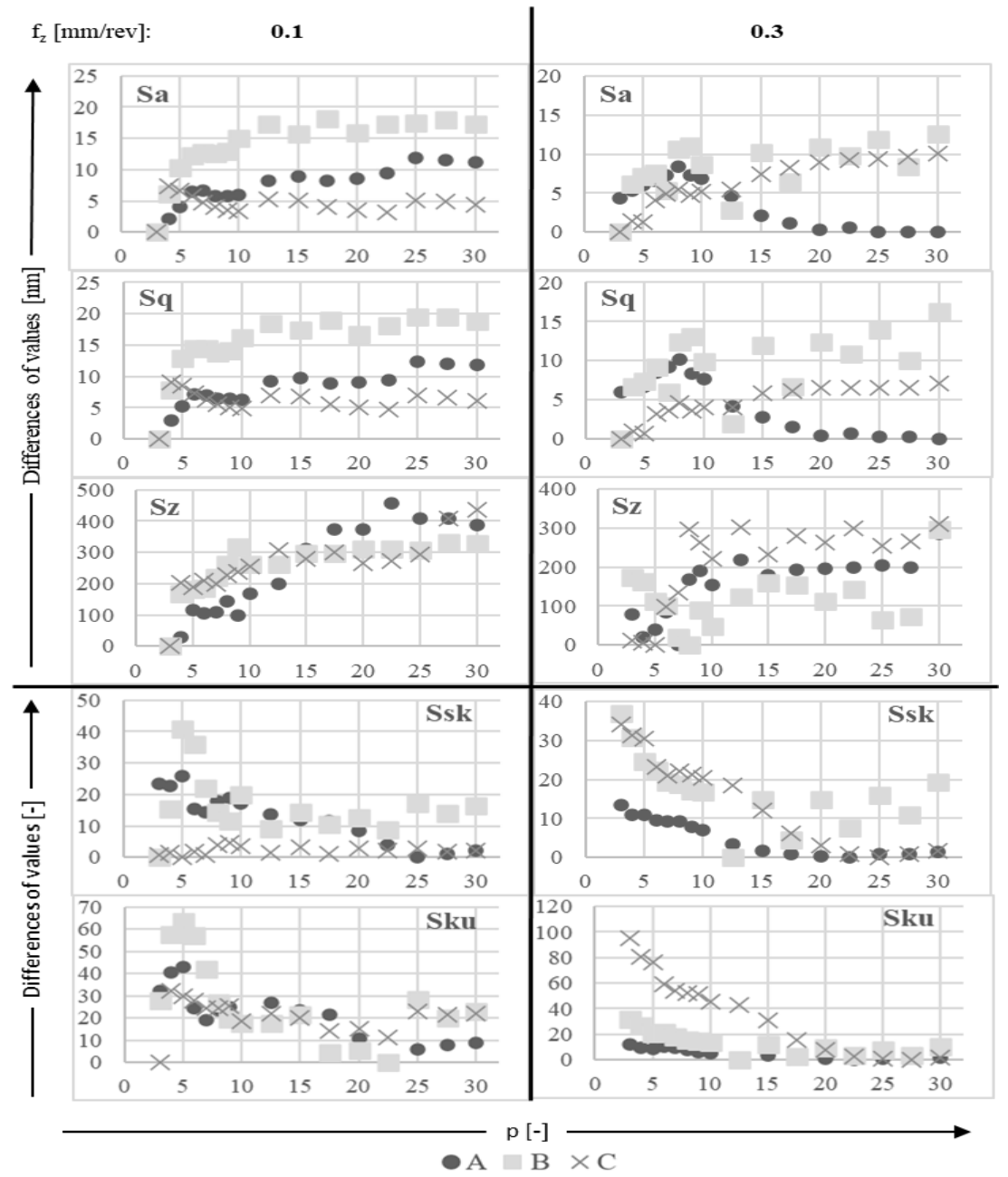

Figure 2 - Relative differences in roughness values by parameter and measurement location 


\section{CONCLUSIONS}

In the present article, we examined the effect of the measurement length on the values of areal roughness parameters at symmetrically face milled surfaces at two feed rates. In doing so, the measurement length was set as a multiple of the feed per tooth and denoted by $p$. The analysis was performed based on the values of five roughness parameters.

We found that at low $p$ values the roughness parameter values changed significantly, while at $p \geq 15$ they are almost the same. Above $p \geq 15$ on both specimens the differences are maximum $1 \%$ for $S_{a}$ and $S_{q}, 7 \%$ for $S_{z}, 3.5 \%$ for $S_{s k}$ and $1.5 \%$ for $\mathrm{S}_{\mathrm{ku}}$. Based on this, when measuring areal roughness a value of at least 15 times $p$ is recommended.

Among the examined roughness parameters, the values of $S_{z}$ showed the largest differences, reaching up to $20 \%$ in the whole study range, however, the ratio was reduced to $9 \%$ even in the case of $p \geq 10$. The increase of the feed rate generally resulted in a slight change in the deviations. The degree of influence of the measurement length on the areal roughness parameters was found to be (in descending order): $S_{\mathrm{z}}, \mathrm{S}_{\mathrm{sk}}, \mathrm{S}_{\mathrm{ku}}, \mathrm{S}_{\mathrm{q}}$, and finally $\mathrm{S}_{\mathrm{a}}$.

References: 1. Pomberger, S., Stoschka, M., Leitner, M.: Cast surface texture characterisation via areal roughness, Precision Engineering vol.60 (2019) pp.465-481. 2. Eifler, M., Klauer, K., Kirsch, B., Seewig, J., Aurich, J. C.: Micro-milling of areal material measures-influences on the resulting surface topography, Procedia CIRP vol.71 (2018) pp.122-127. 3. Karpat, Y.: Influence of diamond tool chamfer angle on surface integrity in ultra-precision turning of singe crystal silicon, The International Journal of Advanced Manufacturing Technology vol.101(5) (2019) pp.1565-1572. 4. Zak, K.: Areal field and fractal based characterization of hard surfaces produced by different machining operations, Journal of Machine Engineering vol.16(1) (2016) pp.24-32. 5. Wüst, P., Edelmann, A., Hellmann, R.: Areal surface roughness optimization of maraging steel parts produced by hybrid additive manufacturing, Materials vol.13(2) (2020) ArtNo:418. 6. Cabanettes, F., Joubert, A., Chardon, G., Dumas, V., Rech, J., Grosjean, C., Dimkovski, Z.: Topography of as built surfaces generated in metal additive manufacturing: a multi scale analysis from form to roughness, Precision Engineering vol.52 (2018) pp.249-265. 7. Charles, A., Elkaseer, A., Thijs, L., Hagenmeyer, V., Scholz, S.: Effect of process parameters on the generated surface roughness of down-facing surfaces in selective laser melting, Applied Sciences vol.9(6) (2019) ArtNo:1256. 8. Nagy, A.: Influence of Measurement Settings on Areal Roughness with Confocal Chromatic Sensor on Face-milled Surface, Rezanie i Instrumenty v Tekhnologicheskih Sistemah vol.93 (2020) pp.65-75. 9. Kundrák, J., Gyáni, K., Felhö, C., Deszpoth, I.: The effect of the shape of chip cross section on cutting force and roughness when increasing feed in face milling, Manufacturing Technology vol.17(3) (2017) pp.335-342. 10. Kundrák, J., Felhö, Cs.: 3D Roughness Parameters of Surfaces Face Milled by Special Tools, Manufacturing Technology vol.16(3) (2016) pp.532-538. 11. Varga, G., Kundrák, J.: Effects of technological parameters on surface characteristics in face milling, Solid State Phenomena vol.261 (2017) pp.285-292. 12. Nagy, A., Kundrák, J.: Changes in the values of roughness parameters on face-milled steel surface, Rezanie i Instrumenty v Tekhnologicheskih Sistemah vol.92 (2020) pp.85-95. 13. David Whitehouse: Surfaces and their Measurement. Butterworth-Heinemann, Oxford, 2004. 14. Todhunter, L. D., Leach, R., Lawes, S., 
Blateyron, F.: Industrial survey of ISO surface texture parameters. CIRP Journal of Manufacturing Science and Technology, vol.19. (2017) pp. 84-92.

\title{
Антал Надь, Мішкольц, Угорщина \\ ДОСЛІДЖЕННЯ ВПЛИВУ ДОВЖИНИ ВИМІРЮВАННЯ ШОРСТКОСТІ НА ТОПОГРАФІЇ ПОВЕРХНІ ПІСЛЯ ТОРЦЕВОГО ФРЕЗЕРУВАННЯ
}

\begin{abstract}
Анотація. Огляд літератури показує, що дослідження змін у налаштуваннях вимірювання шорсткості (розмір вимірюваної області, фільтрація топографій) на поверхнях, оброблених різними методами, виконуються різними способами, $i$ інформація для характеристики $i$ порівняння складається з різних наборів показників шорсткості. Це означає, що не існує єдиного методу вимірювання шорсткості поверхні, і тому поверхні, отримані різними способами, фактично не можуть бути співставлені. У цій статті досліджується ступінь впливу зміни довжини вимірювання на значення шорсткості в залежності від величини швидкості подачі, яка створює періодичність. Це пов'язано з тим, що не всі дослідники зверталися до цього, незважаючи на відносно велику кількість аналізів шорсткості. Для досліджень використовувався прилад для 3D вимірювання шорсткості поверхні типу AltiSurf 5203 конфокальним хроматичним датчиком (CL2). Три ділянки були записані на одній $і$ тій же відстані, з яких середня область була вирівняна по площині симетрії фрезерування. Важливо було одночасно досліджувати кілька ділянок на поверхнях, тому щзо всі частини функціональних поверхонь одночасно з'єднані зі своїми аналогами, де шорсткість відіграє важливу роль. Оиінка проводилася за допомогою програмного забезпечення AltiMap Preтіuт, де після вирівнювання топографії та виключення викидів були встановлені відрізки довжини відповідно до стандарту для двох швидкостей подачі. При ивому довжина вимірювання була встановлена як кратна подачі на зуб і позначена буквою р. Аналіз проводився на основі значень п'яти параметрів шорсткості. Виявлено, щзо при низьких значеннях р, значення параметрів шорсткості істотно змінюються, а при $p \geq 15$ вони практично не відрізняються. Вище $p \geq 15$ для досліджуваних зразків різниия становить максимум $1 \%$ для $S_{a}$ i $S_{q}, 7 \%$ для $S_{3}, 3,5 \%$ для $S_{s k}$ i $1,5 \%$ для $S_{k u}$. Виходячи 3 цього, при вимірюванні шорсткості поверхні рекомендується значення не менше $p \geq 15$. Серед досліджених параметрів шорсткості значення $S_{z}$ показало найбільші відмінності, досягаючи $20 \%$ у всьому досліджуваному діапазоні, проте це співвідношення зменшилося до 9\% навіть в разі $p \geq 10$. Збільшення швидкості подачі зазвичай призводило до невеликої зміни відхилень. Ступінь впливу довжини вимірювання на параметри шорсткості поверхні виявилася (в порядку убування): $S_{z}, S_{s k}, S_{k u}, S_{q} i$, нарешті, $S_{a}$.
\end{abstract}

Ключові слова: шорсткість профілю; шорсткість поверхні; довжина вимірювання. 